\title{
胸腰椎外傷に対する前方固定術の経験
}

一内視鏡視下アプローチと MINIALIF を用いて一

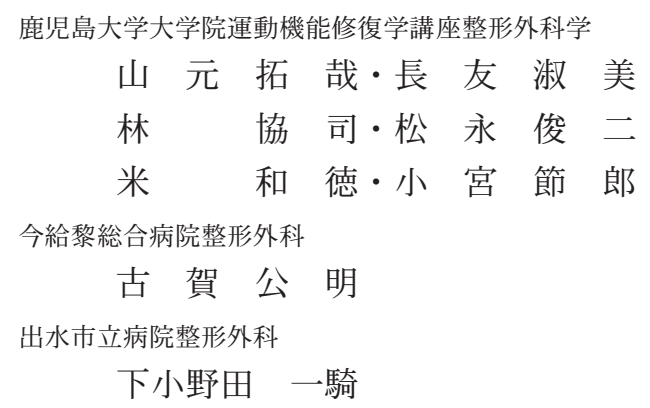

\section{Ventral Fusion to Thoracolumbar Trauma Treated with Endoscopic Surgery and MINIALIF}

Takuya Yamamoto, Yoshimi Nagatomo, Kyoji Hayashi, Shunji Matsunaga, Kazunori Yone, and Setsuro Komiya

Department of Orthopaedic Surgery,

Kagoshima Graduate School of Medical and Dental Sciences, Kagoshima, Japan

\section{Hiroaki Koga}

Department of Orthopaedic Surgery, Imakiire General Hospital, Kagoshima, Japan

\section{Kazuki Shimoonoda}

Department fo Orthopaedis Surgery, Izumi Municipal Hospital, Kagoshima, Japan

Endoscopic or mini-open ventral fusion was performed for thoracolumbar trauma. Two patients were treated with retroperitoneoscopy (Retro), four with thoracoscopy (VATS), and four with mini-open retroperitoneal approach (MINIALIF). Average operation time was 10 hours 12 minutes in Retro, 7 hours 12 minutes in VATS, and 2 hours 50 minutes in MINIALIF. Average blood loss was $2048 \mathrm{~g}, 1718 \mathrm{~g}$, and $1065 \mathrm{~g}$. A patient in Retro had neurological deterioration postoperatively, while a patient in VATS was converted to open surgery.

Key words : thoracolumbar trauma (胸腰椎外傷), endoscopic surgery（内視鏡視下手術）, mini-open surgery（小切開手術）

目

的

我々は胸腰椎移行部の外傷に対し, 症例によっては pedicle screw による整復術後, anterior column support を得るために胸膜外あるいは後腹膜腔へのア プローチで前方固定術を施行してきた. 2002 年 10 月 以降このような症例の前方固定術において，小侵襲を 意図し内視鏡あるいは内視鏡補助下の小切開手術に取 
り組んでいる。当初 L1-2，L1-3 の固定術を行った 2 例で後腹膜腔鏡視下アプローチ (以下 Retro と略す) を行なったが，長時間手術となり，また合併症も惹起 したため 2003 年以後方針を変更，L1/2 より頭側には 胸腔鏡視下アプローチ（以下VATS と略す）を， L2/3 より尾側には小切開後腹膜腔アプローチ（以下 MINIALIF と略す）を用いた. Retro, VATS は，4 つの Portal より $10 \mathrm{~mm}$ の硬性斜視鏡視下にて後腹膜 腔あるいは胸腔内にアプローチする方法であり,

MINIALIF は 5- $6 \mathrm{~cm}$ の一皮切で進入, 専用の開創 器を用い, 直視下あるいは内視鏡補助下に操作を行う 方法である. 今回これらの術式の手術侵襲, 問題点等 につき検討したので報告する.

\section{対象及び方法}

症例は今給黎総合病院にて 2002 年 10 月から 2004 年 7 月までに手術施行した 10 例（男 8 例，女 2 例） である. 手術時平均年齢は 48.4 歳 (21 歳から 67 歳). 骨折椎体は Th12 が 1 例，L1 が 5 例， L2 が 2 例， L3 が 2 例. $\mathrm{AO}$ 分類で A3 (burst fracture) が 8 例, B1 (flexion distraction injury) が 2 例. 全例に tricortical の自家腸骨を用いた前方固定術を施行した. 固定椎間は 2 椎間が 8 例, 1 椎間が 2 例である. Retro 2 例にVATS, MINIALIF を各 4 例に施行 した. VATS, MINIALIF の各 1 例では instrument (Aesuclap MACS-TL) を使用した。これらの症例 に対し手術時間, 術中出血量, 神経症状の推移, 周術 期合併症について調査した.

\section{結果}

平均手術時間は Retro で 10 時間 12 分, VATS で 7 時間 12 分, MINIALIF で 2 時間 50 分であった (図 1)。平均術中出血量は Retro で 2048g, VATS で 1718g, MINIALIF で 1065g であった（図 2)。神経 症状は受傷時 Frankel E であった 6 例は増悪等特に 認めず．Frankel D の 3 例は退院時までに Frankel E に改善した. Retro を施行した 1 例で移植母床骨片 の春柱管内脱転による下肢神経症状の悪化をみた，再 手術を行ったが固定術前ほど回復が得られなかった (図 3)。またVATSの 1 例で肋間動脈損傷による術 後大量出血をみとめた. Open conversion にて止血 を要した.
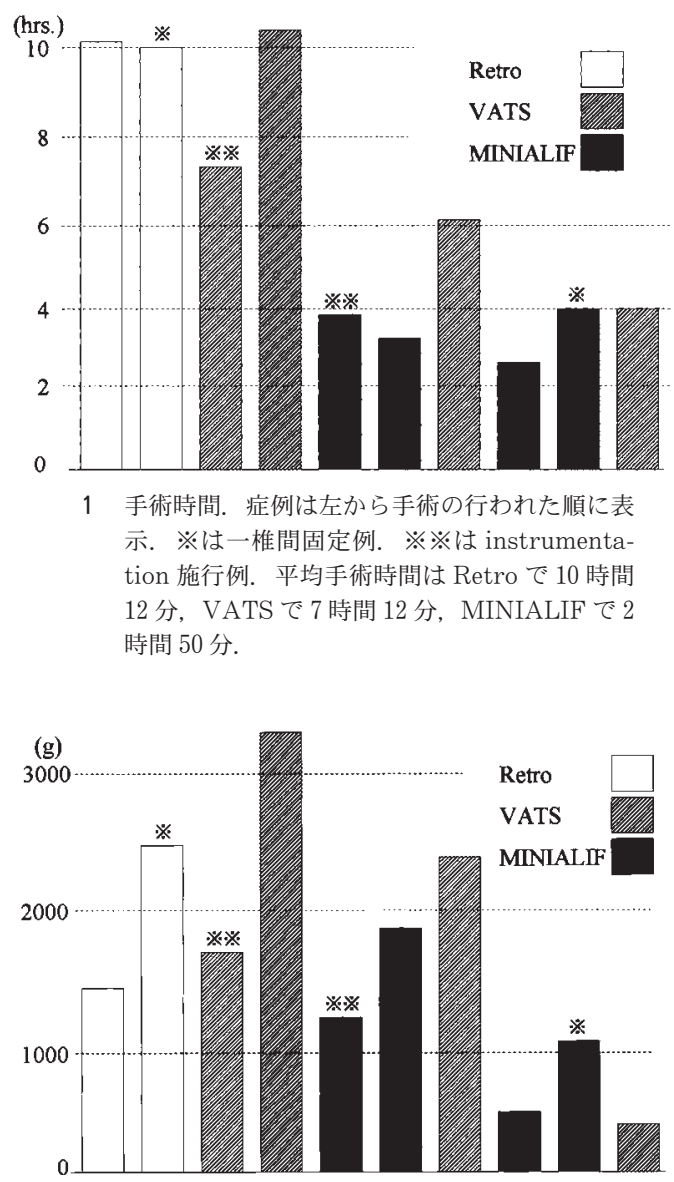

図 2 術中出血量. 症例は左から手術の行われた順に 表示. ※は一椎間固定例. ※※は instrumentation 施行例. 平均術中出血量は Retro で 2048g, VATS で $1718 \mathrm{~g}$, MINIALIF で 1065g.
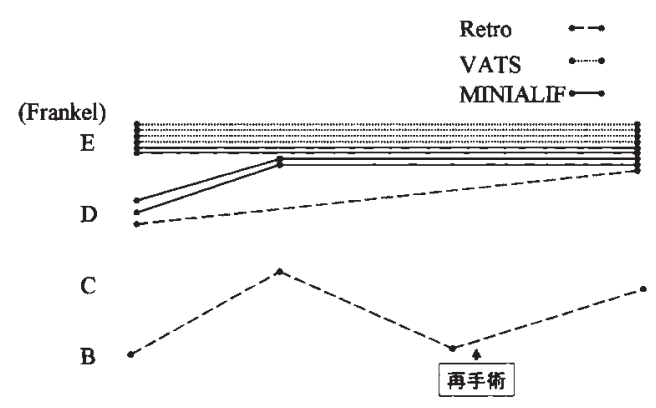

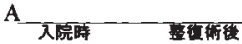

固定雨盀

迶㞣时

図 3 神経症状の推移. Retro の 1 例で移植母床の骨 片の脱出に伴う神経症状の増悪を認めた. 
症例

症例 1. 67 歳男性. $3 \mathrm{~m}$ の高さから転落し L1 の Burst-split fracture 受傷. 神経症状は認めなかった. 後方整復後 21 日目に Aesuculap の MACS-TL を用 いVATS を施行。手術時間 7 時間 35 分, 出血量 1680g であった（図 4).
症例 2. 55 歳男性. $2 \mathrm{~m}$ の高さから転落し L2 の complete burst fracture 受傷. T12 の compression type fracture も認めた。整復術の際 T12には経椎弓 根的に自家骨移植を行った. 14 日後に二期的に L1-3 の MINIALIF を施行. 手術時間 2 時間 50 分, 出血 量 $595 \mathrm{~g}$ であった（図 5).

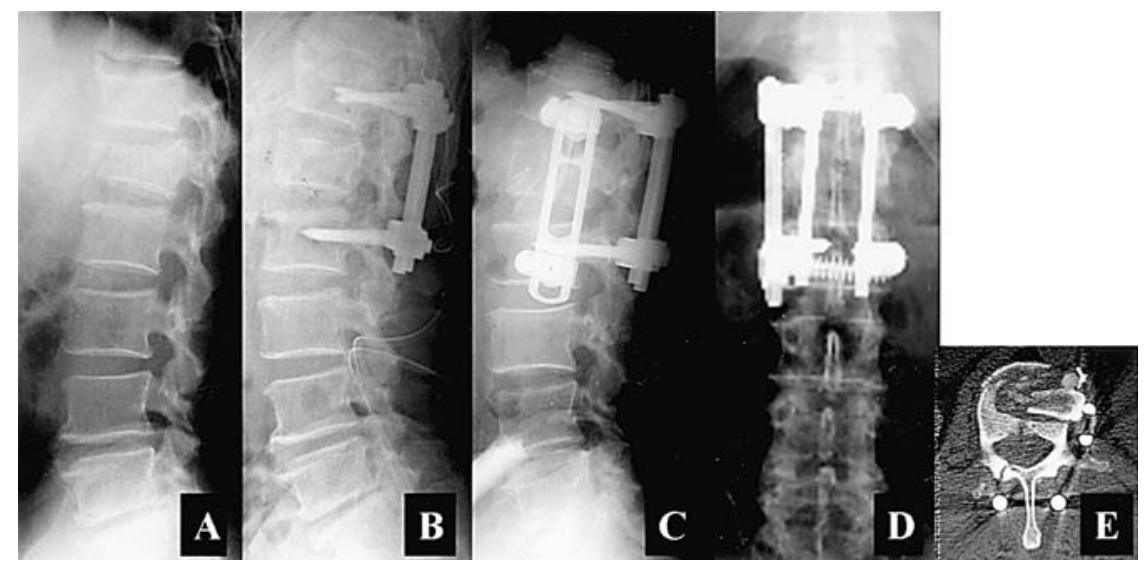

図 4 症例 1.67歳男性. L1のA321（burst-split fracture）にたいし VATS 施行. A：受傷時腰椎側面単純レントゲン。 B : 整復術後腰椎側面単純レントゲン. $\mathrm{C} ：$ 前方固定術後側面単純レントゲン。 D : 前方固定術後正面単純レントゲン $\mathrm{E}:$ 前方固定術後 CT.

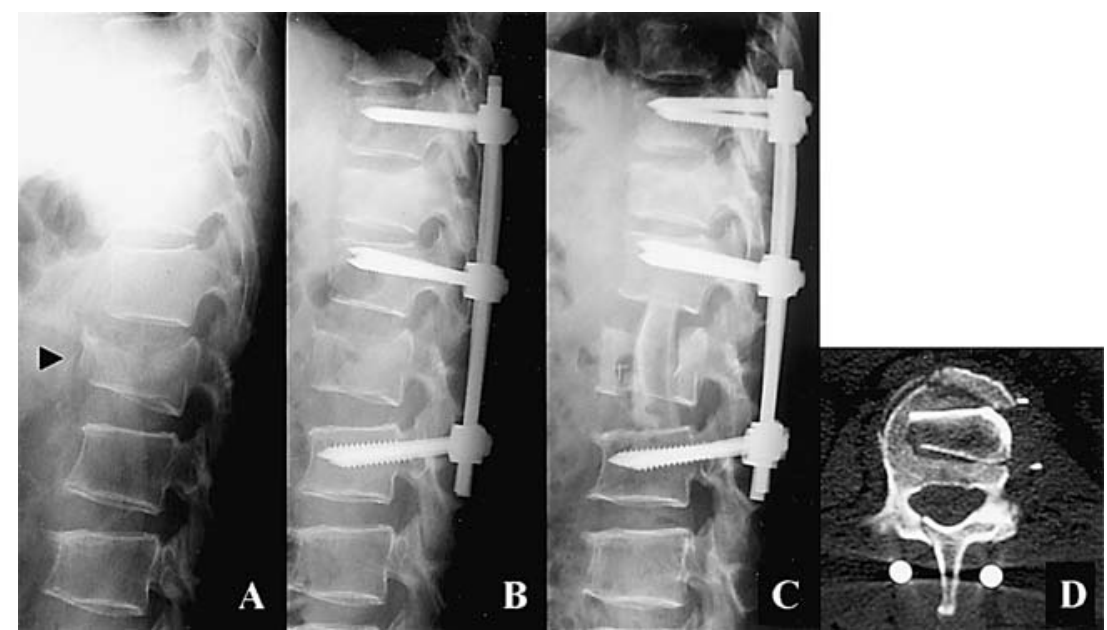

図 5 症例 2.67歳男性. L2 の A331 (complete burst fracture) にたいし MINIALIF 施行. A : 受傷時腰椎側面単純レントゲン。矢印は L 2 を示す。 B : 整復術後腰椎 側面単純レントゲン. T12の compression type fractureに対し経椎弓根的自家 骨移植施行. C : 前方固定術後側面単純レントゲン. D : 前方固定術後 CT. 
考察

Retro, VATS は内視鏡を介しての視野しか得られ 無いこともありオリエンテーションがつきにくく, 深 部感覚や手術手技の修得は決して容易ではない. Retro は後腹膜腔を気腹, あるいはつり上げにて space を作る必要があり, 肋骨があるため直上からの 操作が困難となり横隔膜や胸腰椎移行部の操作が煩雑 である。

VATS は胸腔という space を利用するという点で は，胸椎はそれに適した環境といえる． Beisse $ら^{1)}$ は 椎体骨折に対するVATS での前方固定の成績を報告 し, 前方除圧, instrumentation 併用でも平均手術時 間は 3 時間となったが, 初期は 6 時間以上要したと述 ベており， learning curveの上昇が低侵襲への鍵と なる。またVATS は開胸手術となり片肺換気という 麻酔上の disadvantag があり, 症例によっては胸腔 ドレーンの長期留置が必要となることがある.

MINIALIF は直視下でも操作が可能で conven- tional な手術とほぼ同様の手技であり，肋骨を一部切 除することによって視野も充分に展開しうる. 出沢 ${ }^{2}$ は下位胸椎に対しても小切開進入で肋骨を切除し開胸 せずにアプローチする方法を報告しており，我々も今 後考慮したい. 我々の経験はまだ少なく現時点では侵 襲は大きいが, 低侵襲をめざし今後も発展させていき たいと考えている.

\section{結}

\section{語}

(1)胸腰椎移行部外傷の前方固定において Retro, VATS, MINIALIF を施行した.

(2) Retro, VATSの 1 例で合併症を経験した.

\section{参 考 文 献}

1) Beisse, R., Potulkski, M., Buhren, M.: Minimally invasive spine surgery, 175-186. H.M. Mayer, Berlin, Spriger-Verlag, 2000.

2) 出沢 明: 腰痛疾患に対する各種術式の適応と成績 内視鏡春椎前方固定術横隔膜温存後腹膜胸膜外アプロー チを中心に。骨・関節・勒带, 16 (8)：1034-1040, 2003. 